Bartłomiej Krupowicz

ORCID: 0000-0001-5946-9979

Uniwersytet Jagielloński

https://doi.org/10.19195/1733-5779.37.4

\title{
Uwagi na temat dopuszczalności analogicznego stosowania przepisów o darowiźnie do umowy przekazania nieruchomości
}

\author{
JEL Classification: K11, K12
}

Słowa kluczowe: darowizna, umowa przekazania nieruchomości, analogia, zobowiązania

Keywords: endowment contract, real estate transfer contract, analogy, obligations

\begin{abstract}
Abstrakt: W roku 2008 w miejsce derogowanego art. 179 k.c. wprowadzono do kodeksu cywilnego nową umowę przekazania nieruchomości. Kontrakt ten nie był do tej pory przedmiotem szerszego zainteresowania doktryny prawa cywilnego ani judykatury. Jego krótka regulacja wraz z pewnymi argumentami funkcjonalnymi i systemowymi wskazują na to, że nie jest on w tytule XXXIII ${ }^{1}$ k.c. uregulowany w sposób pełny i można przez analogię stosować do niego pewne instytucje charakteryzujące umowę darowizny. W pracy autor prowadzi polemikę z istniejącymi w doktrynie argumentami przeciwko dopuszczalności tej analogii oraz wskazuje na zakres regulacji umowy darowizny, który można odnieść do przekazania nieruchomości.
\end{abstract}

\section{Comments on possibility of analogical using of endowment contract regulations to real estate transfer contract}

Abstract: In 2008, the derogated article 179 of the Polish Civil Code was replaced by a new type of contract, namely real estate transfer contract. Until now, the contract was not a subject of wider interest of civil law doctrine and judicature. Its short regulation considering some functional and systematic arguments implies that it is not fully regulated in the Title XXXIII ${ }^{1}$ of the Civil Code and it is possible to analogically use for it some institutions characteristic for the endowment contract. In the present article the author discusses the arguments which have appeared in doctrine until now, according to which such an analogy is forbidden and points to the area of endowment contract regulations which can be also compared to real estate transfer. 


\section{Wprowadzenie}

Umowa przekazania nieruchomości regulowana jest w art. $902^{1}$ oraz art. $902^{2}$ kodeksu cywilnego ${ }^{1}$ stosunkowo od niedawna, bo dopiero od 2008 roku $^{2}$. Jej geneza wiąże się z wyrokiem Trybunału Konstytucyjnego z dnia 15 marca 2015 roku, K 9/04³ , w którym uznano art. 179 k.c. za niezgodny z Konstytucją Rzeczypospolitej Polskiej ${ }^{4}$. Ów przepis przewidywał możliwość zrzeczenia się własności nieruchomości przez jednostronną czynność prawną właściciela, dokonywaną $\mathrm{w}$ formie aktu notarialnego. Prawo własności nieruchomości przechodziło wówczas na gminę wraz z obciążeniami na rzecz osób trzecich. Derogacja wspomnianego przepisu skutkowała wprowadzeniem w 2008 roku alternatywy dla uprzednio istniejącej możliwości zrzeczenia się własności nieruchomości, czego efektem jest wprowadzenie do systemu prawa cywilnego umowy przekazania nieruchomości w tytule XXXIII ${ }^{1}$ k.c. ${ }^{5}$ Mamy więc do czynienia z dość nową umową nazwaną, przez co trudno mówić o istnieniu ugruntowanego zapatrywania orzecznictwa na funkcjonowanie przekazania nieruchomości w praktyce. Podobnie brak głębszego zainteresowania problematyką umowy przekazania nieruchomości w doktrynie. Regulowana jest ona zaledwie dwoma, stosunkowo krótkimi — żeby nie powiedzieć lakonicznymi — artykułami kodeksu cywilnego. Może się więc a limine wydawać, że tak oględna regulacja bardzo doniosłego stosunku prawnego wymaga uzupełnienia przez stosowanie do przekazania nieruchomości także innych przepisów wspominanej ustawy. Nie chodzi tu oczywiście o przepisy części ogólnej kodeksu cywilnego — zastosowanie tychże jest bowiem oczywiste i konieczne w przypadku każdej czynności prawnej. Mowa o odpowiednim stosowaniu przepisów o umowie darowizny (art. 888-902 k.c.) w drodze analogii ${ }^{6}$, co uzasadnić należy istotnym podobieństwem w pewnych aspektach obu umów.

1 Ustawa z dnia 23 kwietnia 1964 roku — Kodeks cywilny, Dz.U. z 2020 r. poz. 1740 ze zm. (dalej: k.c.).

2 Ustawa z dnia 23 lipca 2008 roku o zmianie ustawy - Kodeks cywilny oraz ustawy Prawo o notariacie, Dz.U. Nr 163, poz. 1012.

3 OTK-A 2005/3/24.

${ }^{4}$ Konstytucja Rzeczypospolitej Polskiej z 2 kwietnia 1997 roku, Dz.U. z 2009 r. Nr 114, poz. 96.

${ }^{5}$ Obszerniej genezę umowy przekazania nieruchomości zarysowuje M. Safjan, [w:] Kodeks cywilny, t. 2. Komentarz do art. 450-1088, red. K. Pietrzykowski, Legalis 2021, komentarz do art. $902^{1}$, teza 1 i 2 .

${ }^{6}$ G. Jędrejek, Wykładnia przepisów prawa cywilnego materialnego i procesowego, Warszawa 2020, s. 139. Zgadzając się z poglądami G. Jędrejka co do tego, że nie należy utożsamiać analogii z odpowiednim stosowaniem, należy jednak przyjąć konieczność odpowiedniego zastosowania tych regulacji, które w analogii są odnoszone do nieuregulowanego stosunku prawnego. Wynika to z oczywistej odmienności obu stosunków prawnych. Podobnie uważa Z. Woźniak, Umowa o dożywocie w prawie polskim, Warszawa 2019, s. 349. 
Wspomniano już, że na konieczność stosowania uzupełniających przepisów o darowiźnie do umowy przekazania nieruchomości wpływa lakoniczność regulacji doniosłego stosunku prawnego. Skąd jednak przypisanie atrybutu doniosłości tej umowie? Otóż doniosłość umowy przekazania nieruchomości uwidacznia się w tym, że prowadzi ona do przewłaszczenia nieruchomości, które w zamyśle ustawodawcy stanowią jeden z najistotniejszych składników mienia podmiotów prawa. Ta aksjologia zauważalna jest przede wszystkim w szczególnym reżimie obrotu nieruchomościami. Przykładowo można tu wymienić rygoryzm co do formy (art. 158 k.c.), bezwarunkowości przeniesienia własności (art. 157 § 1 k.c.) czy ograniczeń podmiotowych co do osoby nabywców w przypadku szczególnych kategorii nieruchomości (art. 2a ust. 1 ustawy o kształtowaniu ustroju rolnego ${ }^{7}$ oraz art. 1 ust. 1 ustawy o nabywaniu nieruchomości przez cudzoziemców ${ }^{8}$ ). Ze względu na te okoliczności wydaje się zasadne uzupełnienie kwestii w ustawie nieuregulowanych w sposób odpowiedni przez wykorzystanie zbliżonej umowy darowizny. Nie oznacza to rzecz jasna, że wszystkie regulacje, charakterystyczne dla darowizny, można odnieść do umowy przekazania nieruchomości. Wskazanie zakresu dopuszczalności uzupełniającego stosowanie przepisów o darowiźnie do przekazania nieruchomości spełni postulat zapewnienia pewności i klarowności w obrocie nieruchomościami, jednocześnie lepiej, zdaniem autora, oddając ratio legis powołania do życia umowy przekazania nieruchomości.

Warto tu odnotować, że pojawił się w doktrynie pogląd, wyrażony przez M. Safjana9 , kontestujący doniosłość i potrzebę wprowadzenia regulacji umowy przekazania nieruchomości. Jego zdaniem rolę przekazania nieruchomości skutecznie spełniłyby istniejące już dotychczas umowy w kodeksie cywilny, zwłaszcza umowa darowizny. Poglądu tego jednak nie można podzielać. Umowa darowizny, nawet gdy strony nie wprowadzą w niej dodatkowych zastrzeżeń (jak polecenia - art. 893 k.c.), zawiera pewne funkcjonujące ex lege rozwiązania, których istnienie mogłoby zaburzyć obrót nieruchomościami w szczególnych stosunkach, jakimi są relacje cywilnoprawne z gminą i Skarbem Państwa. Mowa o instrumentach funkcjonujących jako naturalia negotii, w szczególności: znacznym ograniczeniu odpowiedzialności darczyńcy za wady przedmiotu darowizny (art. 892 k.c.), obowiązku alimentacji w razie niedostatku darczyńcy (art. 897 k.c.), możliwości odwołania darowizny (art. 898 § 1 k.c.). W razie zawarcia umowy darowizny nieruchomości z gminą lub Skarbem Państwa przepisy te mogłyby znaleźć zastosowanie, co wpłynęłoby niekorzystnie na stabilność obrotu nieruchomościami oraz gospodarkę finansową podmiotów publicznych. Ze względu na

${ }^{7}$ Ustawa z dnia 11 kwietnia 2003 roku o kształtowaniu ustroju rolnego, Dz.U. z 2021 r. poz. 234.

8 Ustawa z dnia 24 marca 1920 roku o nabywaniu nieruchomości przez cudzoziemców, Dz.U. z 2017 r. poz. 2278.

9 M. Safjan, op. cit., teza 2. 
istotny element emocjonalny, który łączy darczyńcę i obdarowanego ${ }^{10}$, będący typowym uzasadnieniem dokonywania darowizny, trudno byłoby tę umowę zastosować wprost do relacji czysto gospodarczych. Nie ulega też wątpliwości, że relacje prawne nawiązywane z podmiotami sektora publicznego wykazują pewną specyfikę $\mathrm{w}$ stosunku do relacji z podmiotami prywatnymi. W pierwszym przypadku, mimo istniejącej w prawie cywilnym zasady równorzędności podmiotów, zazwyczaj, choćby w tle stosunku prawnego, rysuje się przewaga podmiotu publicznego ${ }^{11}$. Strony mogą być wręcz zainteresowane wykluczeniem możliwości powstania komplikacji wynikających z tu wymienionych przepisów, czemu służy umowa przekazania nieruchomości. Przykładowo, zbywca nieruchomości co do zasady nie ma zamiaru odpowiadać za wady zbywanej nieruchomości. W razie zawarcia umowy darowizny odpowiedzialność tę, co prawda w pewnym stopniu ograniczoną, ale ponosiłby (art. 892 k.c.). Z kolei umowa przekazania nieruchomości zwalnia go z tej odpowiedzialności, lepiej oddając interes zbywcy, który chce się „pozbyć” własności nieruchomości z możliwie najmniejszym ryzykiem (art. $902^{2}$ k.c.). Ze względu na główną problematykę pracy dalsza polemika nie będzie jednak rozwijana.

Można więc stwierdzić, że z perspektywy zarówno zbywcy, jak i nabywcy umowa darowizny i umowa przekazania nieruchomości realizują odmienne cele, co też uzasadnia odrębny zakres wzajemnych uprawnień i obowiązków stron. Zdecydowanie większa ich część funkcjonuje w ramach umowy darowizny. Przemawia to przeciwko dokonanemu przez M. Safjana uproszczeniu przez uznanie, że darowizna jest w stanie skutecznie zastąpić przekazanie nieruchomości. Istota problemu nie tkwi bowiem w przeniesieniu własności nieruchomości (obie umowy prowadzą do tego skutku), lecz w sferze wzajemnych praw i obowiązków zbywcy i nabywcy, które w obu zobowiązaniach przedstawiają się odmiennie.

\section{Ogólne warunki skorzystania z analogii w procesie wykładni}

W kolejnych dwóch podrozdziałach zostaną zawarte kolejno: polemika z pojawiającymi się w doktrynie argumentami przemawiającymi przeciwko dopuszczalności analogicznego stosowania przepisów o umowie darowizny do umowy przekazania nieruchomości oraz uzupełniające uzasadnienie poglądów autora na temat możliwości takiej analogii. Należy więc następujące podrozdziały traktować $\mathrm{w}$ istocie jako dowód spełnienia przyjętych w doktrynie i orzecznictwie przesłanek analogii. Wnioskowanie $\mathrm{z}$ analogii, jako nieunormowane $\mathrm{w}$ żadnym przepisie

10 M. Bączyk, L. Stecki, [w:] System Prawa Prywatnego, t. 7. Prawo zobowiązań - część szczegółowa, red. J. Rajski, Warszawa 2018, s. 351.

11 J. Ignatowicz, K. Stefaniuk, A. Wolter, [w:] iidem, Prawo cywilne. Zarys części ogólnej, Warszawa 2017, s. 21. 
prawa $^{12}$, jest dopuszczona przez doktrynę i orzecznictwo metodą wykładni prawa cywilnego. Wobec tego należy pokrótce przedstawić owe przesłanki, których ziszczenie się warunkuje zastosowanie analogii w prawie cywilnym. Oczywiście wśród teoretyków prawa występują pewne różnice poglądów co do zagadnień szczegółowych (zwłaszcza co do tego, czy analogia jest metodą wykładni, czy tylko sposobem wnioskowania prawniczego). Nie jest to jednak przedmiotem niniejszego opracowania, więc nie będzie również przedmiotem polemiki ${ }^{13}$. Autor pozwolił sobie ograniczyć się do przesłanek, które zarówno w teorii prawa, jak i w orzecznictwie Sądu Najwyższego nie budzą wątpliwości.

Pierwszą z przesłanek analogii, niewątpliwie najważniejszą, która decyduje w ogóle o sięgnięciu do tej metody wykładni, jest istnienie luki w prawie ${ }^{14}$. Pod pojęciem luki należy rozumieć sytuację, w której nie ma unormowania określonego stosunku społecznego, a jednocześnie nie jest on prawnie obojętny ${ }^{15}$. Taka definicja, zaproponowana przez A. Brzozowskiego, W.J. Kocota oraz E. Skowrońską-Bocian wydaje się najbardziej przydatna z punktu widzenia prowadzonych dalej rozważań. Kolejne podrozdziały w istocie wskażą, że w odniesieniu do regulacji umowy przekazania nieruchomości mamy do czynienia z niedoregulowaniem owego stosunku prawnego (można wręcz rzec, że prawodawca minus dixit quam voluit), a ponadto kwestie, które nie są ujęte w art. $902^{1} \mathrm{i}$ art. $902^{2}$ k.c., nie są irrelewantne prawnie i wymagają uregulowania (z pewnością istota stosunku prawnego między zbywcą nieruchomości a Skarbem Państwa bądź gminą jest kwestią znaczącą).

Mówiąc o luce prawnej, należy mieć na myśli wyłącznie wystąpienie luki konstrukcyjnej $^{16}$, czyli gdy obiektywnie brakuje regulacji, którą można odnieść do danego stosunku. W ustalaniu, czy występuje luka konstrukcyjna (a nie tylko aksjologiczna, której uzupełnić przez analogię nie można), istotną rolę odgrywa argument oparty na ustaleniu intencji ustawodawcy, który nie uregulował spodziewanej sytuacji prawnej ${ }^{17}$. Nie bez znaczenia będzie także argumentacja systemowa (co jest zwłaszcza istotne w analizowanym przypadku, ponieważ regulacja umowy darowizny i przekazania nieruchomości są wobec siebie sąsiadujące) i funkcjonalna (zwłaszcza w związku z nieodpłatnym charakterem przysporzenia na rzecz obdarowanego/nabywcy nieruchomości z umowy przekazania nieruchomości).

12 G. Jędrejek, op. cit., s. 113.

13 Obszerne zestawienie poglądów na istotę analogii przedstawił M. Walasik, Sposoby pojmowania analogii w prawoznawstwie, [w:] Analogia w prawie procesowym cywilnym, Warszawa 2013.

14 Z. Radwański, M. Zieliński, [w:] System Prawa Prywatnego, t. 1. Prawo cywilne - część ogólna, red. M. Safjan, Warszawa 2012, s. 493-494. Podobnie też Sąd Najwyższy w uchwale z dnia 26 września 1969 roku, III CZP 8/69, OSNC 1970/6/97.

15 A. Brzozowski, W.J. Kocot, E. Skowrońska-Bocian, Wykładnia przepisów prawa cywilnego, [w:] iidem, Prawo cywilne. Część ogólna, Warszawa 2018, s. 107.

16 G. Jędrejek, op. cit., s. 111.

17 S. Wronkowska, Z. Ziembiński, Zarys teorii prawa, Poznań 2001, s. 168. 
Druga z przesłanek analogii to istnienie normy podobnej, która reguluje podobny stan faktyczny ${ }^{18}$. Oczywiście w rozważanym przypadku chodzi o normy regulujące stosunek darowizny. Choć podobieństwo występuje już prima facie, wymaga ono przybliżenia jako fundamentalna odnośnie do proponowanej w niniejszym artykule możliwość analogicznego stosowania pewnych regulacji umowy darowizny do umowy przekazania nieruchomości. W dalszej części rozważań zgłębione zostanie zagadnienie podobieństwa umowy darowizny i umowy przekazania nieruchomości. Zarysowane tu przesłanki analogii wskazują, że mamy do czynienia z przykładem analogia legis.

\section{Dopuszczalność analogicznego stosowania przepisów o darowiźnie do umowy przekazania nieruchomości w literaturze}

Zagadnienie stosowania analogicznie do umowy przekazania nieruchomości przepisów o umowie darowizny w było już częściowo przedmiotem wypowiedzi doktryny, choć nie były to wypowiedzi kompleksowe ani należycie umotywowane. Za zdecydowanie przeważające należy uznać stanowisko przeciwne stosowaniu przepisów o darowiźnie do umowy przekazania nieruchomości ${ }^{19}$. Autorzy, którzy, przyjmują ten pogląd, w większości podają następujące argumenty: dopuszczalność stosowania odpowiedniego przepisu o darowiźnie do przekazania nieruchomości wyłącza art. 889 pkt 1 k.c.; darowizna jest odrębnie uregulowaną względem przekazania nieruchomości umową nazwaną; kauza przysporzenia przy obu umowach jest inna oraz przy umowie przekazania nieruchomości brak jest elementu wdzięczności, charakterystycznego dla darowizny. Wyjątkowo M. Safjan dopuszcza możliwość odpowiedniego stosowania regulacji charakterystycznych dla darowizny do umowy przekazania nieruchomości ${ }^{20}$, który to pogląd należy zaaprobować.

Polemikę z tą argumentacją należy rozpocząć od odniesienia się do poglądu B. Lackorońskiego ${ }^{21}$, który uważa, że możliwość stosowania do przekazania nie-

18 Z. Radwański, M. Zieliński, op. cit., s. 493-494.

${ }_{19}$ B. Lackoroński, [w:] Kodeks cywilny. Komentarz, t. 3B. Zobowiąania. Część szczegółowa. Ustawa o terminach zaplaty w transakcjach handlowych, red. K. Osajda, Legalis 2017, komentarz do art. 902 ${ }^{1}$, teza 10; G. Karaszewski, [w:] Kodeks cywilny. Komentarz, red. J. Ciszewski, P. Nazaruk, LEX 2019, art. 902(1), teza 6; jak się wydaje też S. Dmowski, [w:] Komentarz do Kodeksu cywilnego. Księga trzecia. Zobowiązania, t. 1-2, red. G. Bieniek, LEX 2011, art. 902(1), teza 4; T. Bielska-Sobkowicz, [w:] Kodeks cywilny. Komentarz, t. 5. Zobowiąania. Część szczegółowa, red. J. Gudowski, LEX 2017, art. 902(1), teza 4; J. Kozińska, [w:] Kodeks cywilny. Komentarz, t. 5. Zobowiazania. Część szczególna (art. 765-921(16)), red. M. Fras, M. Habdas, LEX 2018, art. 902(1), teza 9; E. Niezbecka, [w:] Kodeks cywilny. Komentarz, t. 3. Zobowiazania - część szczególna, red. A. Kidyba, LEX 2014, art. 902(1), teza 8.

20 M. Safjan, op. cit., teza 3.

${ }^{21}$ B. Lackoroński, op. cit., teza 10; podobnie, bez odesłania do art. 889 pkt 1 k.c., T. Bielska-Sobkowicz, op. cit., teza 4; E. Niezbecka, op. cit., teza 8. 
ruchomości w sposób odpowiedni przepisów o darowiźnie wyklucza art. 889 pkt 1 k.c. Z pewnością nie jest to stanowisko trafne. Przepis art. 889 pkt 1 k.c. orzeka tylko, że nie stanowi darowizny bezpłatne przysporzenie, gdy zobowiązanie do bezpłatnego świadczenia wynika z umowy regulowanej innymi przepisami kodeksu. Ta regulacja pozwala jedynie na wyraźne odróżnienie umowy darowizny i umowy przekazania nieruchomości, jednoznacznie wskazując, że przekazanie nieruchomości nie stanowi darowizny, pomimo nieodpłatnego przysporzenia na rzecz gminy/Skarbu Państwa, którego dokonuje zbywca nieruchomości. Przepis wcale nie przesądza o tym, że przepisów o darowiźnie nie można stosować analogicznie do innych zobowiązań - taki pogląd zdaje się natomiast wyrażać B. Lackoroński. Oczywiście, nie jest możliwe ich zastosowanie wprost - w tym zakresie art. 889 pkt 1 k.c. jest adekwatną podstawą do wykluczenia bezpośredniego stosowania przepisów o darowiźnie do przekazania nieruchomości. Regulacja ta jednak nie rozstrzyga o niedopuszczalności stosowania w sposób odpowiedni.

Nieco podobną argumentację co B. Lackoroński zastosował Grzegorz Karaszewski. Autor ten stwierdza bowiem, że „Z uwagi na jej [umowy przekazania nieruchomości — przyp. B.K.] normatywne wyodrębnienie nie może ona być traktowana jako rodzaj umowy darowizny [...]"22, a przez to „Niedopuszczalne jest więc stosowanie do komentowanej umowy, nawet w drodze analogii, art. 888902 [...]"23. Nikt nie kwestionuje, że umowa przekazania nieruchomości jest odrębną od darowizny umową nazwaną, zwłaszcza że nie jest jej rodzajem (art. 889 pkt 1 k.c.). Taka konstatacja jest swojego rodzaju truizmem, który jednoznacznie wynika z przepisów kodeksu cywilnego, nie wymaga zatem bliższego omówienia. Stwierdzenie, że umowa przekazania nieruchomości nie jest rodzajem darowizny, przez co nie można do niej stosować odpowiednio przepisów o darowiźnie, sugeruje, jakoby jedynym argumentem przemawiającym za brakiem takiej możliwości było wyodrębnienie umowy przekazania nieruchomości od darowizny. Trudno jednak wówczas wyjaśnić wzmiankę autora o braku możliwości takiego stosowania „nawet w drodze analogii”. Przecież gdyby umowa przekazania nieruchomości była rodzajem darowizny, to stosowanie art. 888-902 k.c. odbywałoby się do niej bezpośrednio. Z tego też powodu nie jest zrozumiałe stanowisko autora, który w jednej myśli łączy de facto możliwość stosowania wymienionych regulacji wprost i per analogiam. Poglądu tego autor jednak nie rozwija i nie precyzuje. Jednocześnie należy zauważyć, że G. Karaszewski nie przytoczył żadnego argumentu na rzecz niemożności stosowania przepisów o darowiźnie do umowy przekazania nieruchomości w drodze analogii. Z pewnością nie jest takim argumentem uwaga, że przekazanie nieruchomości nie jest rodzajem darowizny, gdyż właśnie okoliczność wyodrębnienia obu umów stanowi podstawową przesłanką analogii (z braku możliwości stosowania owych przepisów wprost).

22 G. Karaszewski, op. cit., teza 6.

23 Ibidem. 
Kolejnym argumentem, który ma przemawiać przeciwko odpowiedniemu stosowaniu do umowy przekazania nieruchomości przepisów o umowie darowizny, jest odmienność kauzy przysporzenia po stronie nabywcy. Uznanie, że darowizna i przekazanie nieruchomości cechują się odmienną kauzą ${ }^{24}$, wskazuje na to, że zwolennicy tej teorii odwołują się do subiektywnej koncepcji kauzy. Teoria ta jest jednak krytykowana we współczesnej cywilistyce polskiej ${ }^{25}$. Krytykę tę można uznać za uzasadnioną, ponieważ istotą subiektywnie rozumianej kauzy jest utożsamienie przyczyny przysporzenia z psychicznym motywem, którym kieruje się przysparzający. Uzależniania ważności czynności prawnej od tak nieuchwytnego czynnika, jakim jest cel podmiotu dokonującego czynności przysparzającej, nie można pogodzić $z$ zasadą pewności obrotu prawnego ${ }^{26}$. Za dominującą należy uznać w doktrynie polskiej obiektywną teorię kauzy, która sprowadza się do zgeneralizowania ${ }^{27}$ społeczno-gospodarczych celów przysporzenia w trzy (względnie cztery) kauzy, określane już przez samą istotę czynności prawnej i stanowiące jej treść ${ }^{28}$, to jest causa obligandi vel acquirendi, causa solvendi, causa donandi i causa cavendi (przy założeniu zasadności wyróżnienia ostatniej z nich, co jednak nie jest przedmiotem niniejszej pracy). Istotnie, kauzy te wywodzą się z koncepcji subiektywnej, ale zostały zaakceptowane także na gruncie obiektywnej teorii kauzalności ${ }^{29}$. Autorzy, którzy uważają, że zachodzi odmienność kauzy przy umowach darowizny i przekazania nieruchomości, opierają się — najprawdopodobniej — na koncepcji subiektywnej. Uważają więc, że o odmienności kauzy decyduje inna sytuacja motywacyjna darczyńcy (zbycie związane z pewnym zaufaniem i szczodrobliwością wobec nabywcy) oraz zbywcy w umowie przekazania nieruchomości (przeniesienie własności nieruchomości uzasadnione wyłącznie względami ekonomicznymi; chęć ,,pozbycia się” przynoszącej straty i wymagającej nakładów nieruchomości). Rzeczywiście, na tle subiektywnej koncepcji kauzy dostrzegalna jest różnica co do umotywowania zbycia nieruchomości w ramach obu umów z powodu odmiennego celu społeczno-gospodarczego przysporzenia. Jak jednak wskazano, należy raczej stosować w praktyce koncepcję obiektywną kauzy, która zdecydowanie lepiej realizuje postulat pewności obrotu prawnego i pozwala sądom na rozstrzygnięcie o ważności przysporzenia na podstawie zdecydowanie bardziej zobiektywizowanego i namacalnego kryterium. Przyjmując wówczas założenie, że funkcjonują cztery podstawowe kauzy, mające charakter uogólniony, nie należy mieć wątpliwości, że zarówno darowizna, jak i umowa

24 B. Lackoroński, op. cit., teza 4.

25 Z. Radwański, A. Olejniczak, J. Grykiel, [w:] System Prawa Prywatnego, t. 2. Prawo cywilne-część ogólna, red. Z. Radwański, A. Olejniczak, Warszawa 2019, s. 268-271.

26 Z. Woźniak, op. cit., s. 49.

27 Podobnie trafnie na „stypizowane cele gospodarcze” wskazuje M. Pyziak-Szafnicka, [w:] Kodeks cywilny. Komentarz. Część ogólna, red. P. Księżak, LEX 2014, art. 56, teza 63.

28 Z. Radwański, A. Olejniczak, J. Grykiel, op. cit., s. 271.

29 Ibidem. 
przekazania nieruchomości oparte są na causa donandi. W jednym i drugim przypadku właściciel nieruchomości zamierza bowiem dokonać nieodpłatnego przysporzenia, kosztem swojego majątku, na rzecz gminy albo Skarbu Państwa. Nie czyni tego w celu osiągnięcia korzyści (causa obligandi vel acquirendi) od podmiotu publicznego. Oczywiście korzystanie przez właścicieli nieruchomości z umowy przekazania nieruchomości zawsze jest motywowane chęcią zmniejszenia ponoszenia obciążeń związanych z własnością i posiadaniem nieruchomości. To zwolnienie od wymienionych ciężarów nie jest jednak świadczeniem, które spełnić miałaby gmina czy Skarb Państwa w zamian za uzyskanie własności nieruchomości. Jest to element niejako zewnętrzny, stanowiący pozaumowny skutek zbycia własności nieruchomości. Argumentacja ta odpowiada przyjętemu w doktrynie zgeneralizowaniu celów czynności prawnych (kauzy) nawet wówczas, gdy przysparzający kieruje się jakimś odmiennym, nietypowym zamiarem ${ }^{30}$. Zarówno umowa darowizny, jak i umowa przekazania nieruchomości, wykreowane przez ustawodawcę jako umowy nazwane, zawierają implicite kauzę przysporzenia ${ }^{31}$. Jest nią bez wątpienia causa donandi. Argument o niedopuszczalności stosowania odpowiednio przepisów o darowiźnie do umowy przekazania nieruchomości ze względu na odmienność kauzy przysporzenia (przy założeniu stosowania obiektywnej koncepcji kauzy) w obu zobowiązaniach nie jest zatem trafny.

Wreszcie należy przejść do oceny ostatniego z argumentów, które zdaniem doktryny uniemożliwiają analogiczne stosowanie przepisów o umowie darowizny do przekazania nieruchomości. Chodzi tu o występowanie w umowie darowizny elementu wdzięczności ${ }^{32}$, którego nie ma w wypadku umowy przekazania nieruchomości. Bez wątpienia umowa darowizny i umowa przekazania nieruchomości różnią się motywem co do ich zawarcia. Obdarowaniu podlegają zwykle osoby bliskie darczyńcy, którym ten chce przez nieodpłatne przysporzenia sprawić przyjemność czy się za coś odwdzięczyć. Umowa przekazania nieruchomości jest z kolei umową, której zawarcie jest motywowane pragmatyzmem zbywcy, który dąży do „wyzbycia się” zbędnej i przynoszącej straty nieruchomości. Po stronie nabywcy w tej umowie, ze względu na jego podmiotową specyfikę, trudno w ogóle o ustalenie jakiegokolwiek stosunku emocjonalnego co do nabywanej nieruchomości. Odmienność ta, nazywana przez E. Niezbecką ,elementem wdzięczności”, odgrywać będzie rolę w ramach odpowiedniego stosowania przepisów o darowiźnie do przekazania nieruchomości. Zdaniem autora brak elementu wdzięczności nie jest jednak przekonującym argumentem do niestosowania w ogóle przepisów o darowiźnie odpowiednio do przekazania nieruchomości. Jak już wyjaśniono, mówienie o wdzięczności prowadzi nas do subiektywnego spojrzenia na relacje

30 M. Pyziak-Szafnicka, op. cit., teza 63.

31 Na fakt, że poszczególne umowy nazwane już same w sobie zawierają kauzę, wskazuje M. Pyziak-Szafnicka, op. cit., teza 67.

32 Argument ten szczególnie podkreśla E. Niezbecka, op. cit., teza 6. 
kontraktowe między zbywcą nieruchomości a jej nabywcą. Zbliżamy się zatem raczej do pojęcia kauzalności w ujęciu teorii subiektywnej. W tym znaczeniu z pewnością ,element wdzięczności” odgrywa ważną rolę. Nie jest to jednak przesłanka, której wystąpienie uniemożliwia odpowiednie stosowanie do umowy przekazania nieruchomości przepisów o darowiźnie. Należy ją jednak o tyle uwzględniać, że będzie ona wyznaczać zakres i sposób odpowiedniego stosowania regulacji darowizny do przekazania nieruchomości.

Wśród przepisów regulujących umowę darowizny można bowiem wyróżnić zarówno takie, których uzasadnienie nawiązuje do aktu szczodrobliwości (przede wszystkim obowiązek alimentacyjny z art. 897 k.c. czy odwołanie z powodu rażącej niewdzięczności — art. 898 § 1 k.c.), jak i mające walor bardziej ekonomiczny, związany z nieodpłatnością przysporzenia — to jest czynnością generującą po stronie darczyńcy nierekompensowany uszczerbek majątkowy. W ten sposób można uzasadniać ograniczony zakres odpowiedzialności darczyńcy za naruszenie zobowiązania (art. $891 \S 1$ k.c.), za wady przedmiotu darowizny (art. 892 k.c.), dopuszczalność odwołania niewykonanej darowizny ze względu na groźbę niedostatku darczyńcy (art. 896 k.c.) oraz możliwość odwołania darowizny przez przedstawiciela ustawowego darczyńcy (art. $901 \S 1$ k.c.). Jeśli zastanowimy się nad ekonomiczną podstawą tych regulacji, to wydaje się jasne, że są one korelatem nieodpłatności przysporzenia. Ze względu na i tak istotny zakres obciążenia majątkowego darczyńcy ustawodawca zwalnia go od pewnych obowiązków, które w odpłatnych stosunkach prawnych mają charakter standardowy - dotyczy to zwłaszcza regulacji art. $891 \S 1$ oraz art. 892 k.c. Odpowiada to wręcz rzymskiej koncepcji utilitas, zgodnie z którą zakres wymaganej staranności kontrahenta jest większy wówczas, gdy ze zobowiązania uzyskuje on korzyść. W modelowym stosunku zobowiązaniowym odpłatnym, jakim jest umowa sprzedaży, ustawodawca przewiduje znaczną odpowiedzialność za niewykonanie zobowiązania (na zasadzie art. 471 n. k.c.) oraz za wady rzeczy sprzedanej (art. $556^{1}$ n. k.c.). Podobnie uzasadnić można instytucje z art. 896 k.c. i art. $901 \S 1$ k.c. Nieodpłatne przysporzenie obdarowanego łączyć się może ze znacznym obciążeniem jego majątku, które nie jest w żaden sposób kompensowane przez wzajemne świadczenie obdarowanego (nie licząc polecenia, które jednak, w myśl art. 893 k.c., nie czyni nikogo wierzycielem). Wobec tego ustawodawca, nawet po zawarciu węzła obligacyjnego między obdarowanym a darczyńcą, zezwala w art. 896 k.c. i art. $901 \S 1$ k.c. na jego unicestwienie przez odwołanie darowizny. Prymat interesu darczyńcy uzasadniony jest w tych wypadkach groźbą niedostatku (art. 896 k.c.) i nadmiernego obciążenia swojego majątku przez darczyńcę, który został po dokonaniu darowizny ubezwłasnowolniony. W tym drugim przypadku dość krótki termin na żądanie rozwiązania darowizny przez przedstawiciela ustawowego (dwa lata od dokonania darowizny - $901 \S 2$ k.c.) wyraźnie podkreśla, że ustawodawca zdaje sobie sprawę z ryzyka, że osoba dokonująca darowizny w stosunkowo krótkim 
okresie przed orzeczeniem swojego ubezwłasnowolnienia, może nie działać racjonalnie. $Z$ tych też względów decyduje udzielić jej ochrony ${ }^{33}$ za pośrednictwem przedstawiciela ustawowego. Nie można oczywiście wykluczyć, że ratio legis wymienionych rozwiązań prawnych także w pewnym zakresie wynika z bliskości relacji darczyńcy i obdarowanego, ale głównym wydaje się czynnik nieodpłatności przysporzenia.

Reasumując, czynniki wdzięczności i szczodrobliwości nie są przesłankami, których występowanie przy umowie darowizny przekreśla dopuszczalność odpowiedniego stosowania przepisów ją regulujących do umowy przekazania nieruchomości. Mają jednak one o tyle istotne znaczenie, że muszą być rozważane przy ocenie zakresu owego odpowiedniego stosowania. $Z$ tych względów tworzą one swoisty „filtr”, pozwalający wyselekcjonować przepisy, które do umowy przekazania nieruchomości można odpowiednio zastosować. Jak wskazano wcześniej: będą to przepisy, których funkcjonowanie uzasadnione jest czynnikami głównie ekonomicznymi, o możliwie niskim nasyceniu „elementem wdzięczności”.

\section{Argumenty za możliwością analogicznego stosowania przepisów o umowie darowizny do umowy przekazania nieruchomości}

Przedstawienie argumentów za dopuszczalnością odpowiedniego stosowania do umowy przekazania nieruchomości przepisów o darowiźnie należy rozpocząć od uwagi, że w istocie część z nich została już przedstawiona, co jest skutkiem polemiki z wątpliwymi argumentami doktryny przemawiające przeciwko takiemuż stosowaniu. Można więc przypomnieć, że argumentami tymi są: brak stosownego wyłączenia wśród przepisów regulujących przekazania nieruchomości oraz darowizny (w szczególności nie odgrywa takiej roli art. 889 pkt 1 k.c.); systemowe ulokowanie tytułu XXXIII i XXXIII ${ }^{1}$ k.c. obok siebie (nie jest kontrargumentem fakt, że umowy te są odrębnymi umowa nazwanymi - to bowiem warunkuje dopuszczalność zabiegu analogicznego stosowania); tożsamość kauzy w obu umowach oraz ekonomiczne uzasadnienie funkcjonowania niektórych przepisów regulujących darowiznę, odpowiadające ekonomicznym racjom leżącym u podstaw umowy przekazania nieruchomości.

Obszerniej należy odnieść się do poglądu M. Safjana, który jednak tylko lakonicznie wzmiankował dopuszczalność odpowiedniego stosowania do umowy przekazania nieruchomości przepisów o darowiźnie. Jak twierdzi uczony: „Wydaje się, że z uwagi na nieodpłatny charakter przysporzenia należy do tej umowy stosować odpowiednio przepisy o darowiźnie"34. Z tego krótkiego spostrzeżenia autor artykułu wnioskuje jednak, że M. Safjan zgadza się z prezentowanym w ni-

33 Potrzebę ochrony darczyńcy jako ratio legis art. 901 k.c. zauważają też M. Bączyk, L. Stecki, op. cit., s. 404.

34 M. Safjan, op. cit., teza 3. 
niejszym opracowaniu poglądem co do tego, że istotnym argumentem za możliwością stosowania do umowy przekazania nieruchomości regulacji dotyczących darowizny jest tożsamość kauzy. Po raz kolejny jednak należy przypomnieć, że autor tych słów opowiada się za obiektywną koncepcją kauzy, która swoje źródło — jak wiele instytucji polskiego prawa cywilnego - znajduje w doktrynie niemieckiej. Nieodpłatny charakter przysporzenia to bez wątpienia szczególna cecha zobowiązań, które reguluje prawo polskie. Większość bowiem stosunków zobowiązaniowych, które mają ustawową regulację, funkcjonuje jako umowy odpłatne. Wówczas świadczenie jednej ze stron jest odpowiedzią na świadczenie drugiej strony (niezależnie od tego, czy umowa ta będzie wzajemna w rozumieniu art. $487 \S 2$ k.c.). Wyjątkowy charakter przysporzeń pod tytułem darmym bywa uzasadniany zasadami współżycia społecznego, które nakazują sądzić, że standardowym zachowaniem w społeczeństwie jest dokonywanie czynności na rzecz innych w zamian za wzajemną korzyśśc ${ }^{35}$. Jednocześnie wśród nielicznych zobowiązań obejmujących przysporzenie pod tytułem darmym darowizna uchodzi za modelowe zobowiązanie nieodpłatne. To powinno skłaniać do szukania podobieństw między poszczególnymi zobowiązaniami nieodpłatnymi i przemawiać za dopuszczeniem analogicznego stosowania regulacji darowizny, jako stosunku o charakterze wzorcowym, do innych stosunków istotnie podobnych. Warto zauważyć, że w wypadku powołania przez strony w granicach swobody umów (art. $353^{1}$ k.c.) zobowiązania nienazwanego, obejmującego nieodpłatne przysporzenie na rzecz jednej strony, naturalne wydaje się poszukiwanie regulacji, która może do takiego stosunku znaleźć zastosowanie przez analogię, w przepisach o darowiźnie.

Jak wskazano - i jak dostrzega się to też w literaturze ${ }^{36}$ - w regulacji umowy darowizny występują przepisy, których uzasadnieniem jest nieodpłatny charakter świadczenia darczyńcy. Mowa tu o przepisach, które przyznają obdarowanemu węższy zakres ochrony, niż by to wynikało z przepisów ogólnych prawa zobowiązań. Można więc przypomnieć, że chodzi o regulację art. $891 \S 1$, art. 892, art. $896 \mathrm{i}$ art. $901 \S 1$ k.c. W celu odpowiedzi na pytanie, czy istnieje podstawa do ich stosowania przez analogię do umowy przekazania nieruchomości, należy najpierw ustalić, w jakim zakresie powinien uzyskać ochronę nabywca nieruchomości w przypadku umowy przekazania nieruchomości. W wypadku darowizny, gdy stroną obdarowaną jest osoba fizyczna, blisko związana z darczyńcą, ustawodawca nie waha się osłabić przysługującej mu ochrony kontraktowej na wypadek naruszenia zobowiązania przez darczyńcę, wad darowanego przedmiotu, powstania po stronie darczyńcy ryzyka niedostatku czy wreszcie następującego po dokonaniu darowizny ubezwłasnowolnienia darczyńcy. W wypadku zaś umowy przekazania nieruchomości nabywcą jest podmiot o bardzo dużych zasobach

35 Na tle uzasadnienia kauzalności Z. Woźniak, op. cit., s. 63; uwagi te można jednak z powodzeniem odnieść do przysporzeń nieodpłatnych.

36 B. Lackoroński, op. cit., komentarz do art. 888, teza 5. 
ekonomicznych i potencjale finansowym - osoba prawna w postaci gminy położenia nieruchomości lub Skarb Państwa. Nie istnieją, zdaniem autora, racjonalne podstawy, by przyznawać tym bardzo szczególnym kontrahentom ochronę silniejszą niż ochrona obdarowanego z umowy darowizny. Skoro ustawodawca udziela zawężonej ochrony prawnej typowemu obdarowanemu, będącemu osobą fizyczną, blisko związaną z obdarowanym, to - w pewnym sensie a fortiori nie potrzebuje takiej ochrony nabywca o bardzo dużych zasobach finansowych i pozycji majątkowej, który również nabywa własność rzeczy w drodze nieodpłatnego przysporzenia. Argument ten wspiera sam ustawodawca, jeśli przyjrzeć się brzmieniu art. $902^{2}$ k.c. Przepis ten jest wyrazem tego, że legislator zdaje sobie sprawę, że umowa przekazania nieruchomości ma doprowadzić do wyzbycia się przez dotychczasowego właściciela ,,problematycznej” nieruchomości, jak też że jej kolejnym właścicielem staje się bardzo szczególny podmiot prawa cywilnego, który nie wymaga większej ochrony. Dlatego ustawodawca zwalnia zbywcę nieruchomości z odpowiedzialności za wady przekazanej nieruchomości. Inaczej dzieje się w wypadku darowizny, tu obdarowanego chroni, przynajmniej częściowo, art. 892 k.c. Z punktu widzenia aksjologii ustawodawcy wydaje się więc tym bardziej zasadne ograniczenie stosunkowo korzystnej pozycji gminy lub Skarbu Państwa jako kontrahenta, skoro sam ustawodawca uprawnienia nabywcy częściowo uchyla w art. $902^{2}$ k.c., niejako dając wytyczną interpretacyjną co do tego, w jakim zakresie ochrony prawnej chciałby udzielić nabywcy nieruchomości. Warto więc wskazać, że wszystkie przytoczone przepisy (art. $891 \S 1$, art. 892, art. 896, art. $901 \S 1$ k.c.) są właśnie przepisami ograniczającymi korzystność pozycji prawnej obdarowanego. Idąc za wskazówką ustawodawcy z art. $902^{2}$ k.c., należałoby je, oprócz oczywiście art. 892 k.c., także odnieść odpowiednio do sytuacji gminy lub Skarbu Państwa jako nabywcy nieruchomości z umowy przekazania nieruchomości.

W świetle przedstawionych rozważań wydaje się więc, że należy dopuścić analogię z niektórych przepisów regulujących umowę darowizny do umowy przekazania nieruchomości. Spełnione są bowiem obie przesłanki dopuszczalności analogii, o których była tu mowa. Opierając się na poglądach S. Wronkowskiej i Z. Ziembińskiego ${ }^{37}$, należy zauważyć, że po odwołaniu do „domniemanych uzasadnień aksjologicznych", które można przypisać ustawodawcy co do regulacji umowy przekazania nieruchomości oraz darowizny, zasadne jest wnioskowanie a simili.

\section{Konkluzja - zakres dopuszczalnej analogii}

Z zaprezentowanych dotychczas rozważań można już wywnioskować, że dozwolona analogia może ograniczyć się tylko do tych regulacji, które w umowie darowizny oparte są na racjach ekonomicznych w postaci nieodpłatności przy-

37 S. Wronkowska, Z. Ziembiński, op. cit., s. 169. 
sporzenia. Wobec tego należy wykluczyć analogię z przepisów art. 892-895, art. 897-898 k.c. oraz art. 902 k.c. Artykuł 892 k.c. nie może zostać zastosowany do przekazania nieruchomości ze względu na jednoznaczne brzmienie art. $902^{2}$, który zwalnia zbywcę z odpowiedzialności za wady nieruchomości (przepis jest jednak dyspozytywny, więc nie można wykluczyć przyjęcia przez zbywcę odpowiedzialności za te wady). Artykuł 893-895 k.c. dotyczą polecenia. Wydaje się, że usprawiedliwić można obciążenie nabywcy poleceniem, tylko gdy jest to osoba bliska zbywcy. Istotna doza relacji emocjonalnych między kontrahentami może uzasadniać oczekiwanie, by otrzymujący przysporzenie dokonał oznaczonej czynności, niejako w geście wdzięczności i szacunku dla darczyńcy. Trudno odnaleźć podobne racje w wypadku umowy przekazania nieruchomości, gdy kontrahenci są osobami wobec siebie obcymi - ponadto nabywca jest osobą prawną. Podobnie druga grupa przepisów opiera się na mocnym związku emocjonalnym między kontrahentami. O ile nie budzi raczej wątpliwości emocjonalne uzasadnienie dopuszczalności odwołania darowizny z powodu rażącej niewdzięczności obdarowanego (art. 898 k.c.), gdyż mówienie o rażącej niewdzięczności niejako ex definitione zakłada, że między stronami dotychczas utrzymywały się bliskie i poprawne relacje osobiste, to pewnego komentarza może wymagać niedopuszczalność analogii z art. 897 k.c. Przepis ten przewiduje obowiązek alimentacji ze strony obdarowanego na rzecz darczyńcy, gdy po dokonaniu darowizny ten drugi popadł w niedostatek. In abstracto mogłoby się wydawać, że przepis ten ma charakter czysto ekonomiczny. Należy sobie jednak uświadomić, że analiza ta przeprowadzona powinna być in concreto, gdyż odbywa się w perspektywie analogii do umowy przekazania nieruchomości, w której kontrahentem zbywcy jest osoba prawna, będąca dla zbywcy obca. Wobec typowego obdarowanego, będącego osobą fizyczną i blisko związaną ze zbywcą, można zauważyć moralny obowiązek alimentacji (a w standardowej sytuacji, gdy obdarowanym jest osoba związana z darczyńcą stosunkiem prawnorodzinnym, wręcz ustawowy obowiązek - art. 128 kodeksu rodzinnego i opiekuńczego ${ }^{38}$ ) - to w wypadku nabywcy nieruchomości o charakterze publicznym nie sposób oczekiwać od niego utrzymywania zbywcy nieruchomości, który świadomie zbywa nieruchomość nieodpłatnie, chcąc uniknąć kłopotliwych obciążeń publicznoprawnych. W ten sposób zbywca nieruchomości w pewnym sensie sam pozbawia się majątku, który powinien zapewnić mu utrzymanie - zastosowanie art. 897 k.c. przez analogię do przekazania nieruchomości prowadziłoby do absurdalnego obciążenia gminy/ Skarbu Państwa obowiązkiem alimentacji osoby zupełnie emocjonalnie z nimi niezwiązanej, która za ewentualny stan niedostatku jest ponadto sama odpowiedzialna. Zbywca mógł przecież dokonać sprzedaży nieruchomości, czym zapewniłby sobie środki utrzymania. Artykuł 902 k.c. można byłoby odnieść tylko do

38 Ustawa z dnia 25 lutego 1964 roku — Kodeks rodzinny i opiekuńczy, Dz.U. 1964 Nr 9, poz. 59 ze zm. 
stosowanego analogicznie art. 896 k.c. (por. dalej). Ze względu na nieistnienie stosunków osobistych między zbywcą a gminą/Skarbem Państwa trudno jednak mówić, by zaistniałe między nimi relacje czyniły odwołanie umowy przekazania nieruchomości sprzecznym z zasadami współżycia społecznego. Kontrahentów z umowy przekazania nieruchomości łączą relacje wyłącznie ekonomiczne.

Analogiczne zastosowanie znajdzie za to art. $891 \S 1$ k.c. Tym samym zbywca nieruchomości będzie odpowiadać za niewykonanie/nienależyte wykonanie zobowiązania tylko wówczas, gdy doprowadził do niego umyślnie lub wskutek rażącego niedbalstwa. Mając na względzie, że umowa przekazania nieruchomości zobowiązuje tylko zbywcę do przeniesienia własności bez ekwiwalentu ze strony nabywcy - a jednocześnie co do zasady wywiera skutek rzeczowy (art. 155 $\S 1$ k.c.) — można przykładowo podać sytuację, w której strony zawarły umowę o skutku wyłącznie zobowiązującym. Jeśli wówczas zbywca nie złoży oświadczenia o przeniesieniu własności umyślnie lub przez rażące niedbalstwo, będzie odpowiadać wobec nabywcy za ewentualną szkodę. Należy też opowiedzieć się za stosowaniem art. 896 k.c. w wyniku analogii do umowy przekazania nieruchomości. Dotyczy to sytuacji, w której strony zawarły umowę przekazania nieruchomości o skutku tylko zobowiązującym lub nawet o podwójnym skutku, ale nie doszło do wydania nieruchomości, co odpowiada wykonaniu darowizny ${ }^{39}$. Między zawarciem umowy przekazania nieruchomości a jej wykonaniem może upłynąć dłuższy czas, w którym zbywca popadnie w stan grożący istotnym pogorszeniem możliwości utrzymania się z przyczyn przez siebie niezawinionych. Zdaniem autora zasadnie można szukać wśród ratio legis unormowania z art. 896 k.c. elementów gospodarczych, związanych z nieodpłatnością przysporzenia ${ }^{40}$. Nieistnienie zobowiązania po stronie nabywcy uzasadnia umożliwienie także zbywcy skorzystania z odwołania niewykonanej umowy przekazania nieruchomości, gdy jej dokonanie spowodowałoby po jego stronie istotne naruszenie stopy życiowej. Można też dopuścić analogiczne stosowanie do przekazania nieruchomości regulacji z art. 901 $\S 1$ k.c. Jak wykazywano, jej funkcją jest ochrona osoby, która w stanie bliskim ubezwłasnowolnienia dokonała nieodpłatnego przysporzenia na rzecz innego podmiotu, naruszając istotnie swój majątek. Instytucja żądania rozwiązania darowizny, z której może skorzystać przedstawiciel ustawowy ubezwłasnowolnionego, nie czerpie uzasadnienia z osobistych relacji darczyńcy i obdarowanego. Można ją więc efektywnie przenieść na grunt umowy przekazania nieruchomości.

De lege ferenda warto, by ustawodawca wprowadził jednoznaczną regulację przesądzającą o odpowiednim stosowaniu niektórych rozwiązań z umowy darowizny do umowy przekazania nieruchomości.

39 Postanowienie Sądu Najwyższego z dnia 5 czerwca 2018 roku, IV CSK 27/18, LEX nr 2509658

40 Podobnie J. Jezioro, [w:] Kodeks cywilny. Komentarz, red. E. Gniewek, P. Machnikowski, Legalis 2019, komentarz do art. 896, teza 1. 


\section{Bibliografia}

Bączyk M., Stecki L., [w:] System Prawa Prywatnego, t. 7. Prawo zobowiazań - część szczegółowa, red. J. Rajski, Warszawa 2018.

Bielska-Sobkowicz T., [w:] Kodeks cywilny. Komentarz, t. 5. Zobowiązania. Część szczegółowa, red. J. Gudowski, LEX 2017.

Brzozowski A., Kocot W.J., Skowrońska-Bocian E., Wykładnia przepisów prawa cywilnego, [w:] A. Brzozowski, W.J. Kocot, E. Skowrońska-Bocian, Prawo cywilne. Część ogólna, Warszawa 2018.

Dmowski S., [w:] Komentarz do Kodeksu cywilnego. Księga trzecia. Zobowiqzania, t. 1-2, red. G. Bieniek, LEX 2011.

Ignatowicz J., Stefaniuk K., Wolter A., Prawo cywilne. Zarys części ogólnej, Warszawa 2017.

Jezioro J., [w:] Kodeks cywilny. Komentarz, red. E. Gniewek, P. Machnikowski, Legalis 2019.

Jędrejek G., Wyktadnia przepisów prawa cywilnego materialnego i procesowego, Warszawa 2020.

Karaszewski G., [w:] Kodeks cywilny. Komentarz, red. J. Ciszewski, P. Nazaruk, LEX 2019.

Kozińska J., [w:] Kodeks cywilny. Komentarz, t. 5. Zobowiąania. Część szczególna (art. 765 921(16)), red. M. Fras, M. Habdas, LEX 2018.

Lackoroński B., [w:] Kodeks cywilny. Komentarz, t. 3B. Zobowiąania. Część szczegółowa. Ustawa o terminach zapłaty $w$ transakcjach handlowych, red. K. Osajda, Legalis 2017.

Niezbecka E., [w:] Kodeks cywilny. Komentarz, t. 3. Zobowiazania - część szczególna, red. A. Kidyba, LEX 2014.

Pyziak-Szafnicka M., [w:] Kodeks cywilny. Komentarz. Część ogólna, red. P. Księżak, LEX 2014.

Radwański Z., Olejniczak A., Grykiel J., [w:] System Prawa Prywatnego, t. 2. Prawo cywilne część ogólna, red. Z. Radwański, A. Olejniczak, Warszawa 2019.

Radwański Z., Zieliński M., [w:] System Prawa Prywatnego, t. 1. Prawo cywilne - część ogólna, red. M. Safjan, Warszawa 2012.

Safjan M., [w:] Kodeks cywilny, t. 2. Komentarz do art. 450-1088, red. K. Pietrzykowski, Legalis 2021.

Walasik M., Analogia w prawie procesowym cywilnym, Warszawa 2013.

Woźniak Z., Umowa o dożywocie w prawie polskim, Warszawa 2019.

Wronkowska S., Ziembiński Z., Zarys teorii prawa, Poznań 2001.

\section{Akty prawne}

Konstytucja Rzeczypospolitej Polskiej z dnia 2 kwietnia 1997 roku uchwalona przez Zgromadzenie Narodowe w dniu 2 kwietnia 1997 roku, przyjęta przez Naród w referendum konstytucyjnym w dniu 25 maja 1997 roku, podpisana przez Prezydenta Rzeczypospolitej Polskiej w dniu 16 lipca 1997 roku, Dz.U. z 1997 r. Nr 78, poz. 483.

Ustawa z dnia 24 marca 1920 roku o nabywaniu nieruchomości przez cudzoziemców, Dz.U. z 1920 r. Nr 31, poz. 178 ze zm.

Ustawa z dnia 25 lutego 1964 roku — Kodeks rodzinny i opiekuńczy, Dz.U. z 1964 r. Nr 9, poz. 59 ze zm.

Ustawa z dnia 23 kwietnia 1964 roku — Kodeks cywilny, Dz.U. z 1964 r. Nr 16, poz. 93 ze zm.

Ustawa z dnia 11 kwietnia 2003 roku o kształtowaniu ustroju rolnego, Dz.U. z 2003 r. Nr 64, poz. $592 \mathrm{ze} \mathrm{zm}$.

Ustawa z dnia 23 lipca 2008 roku o zmianie ustawy — Kodeks cywilny oraz ustawy Prawo o notariacie, Dz.U. z 2008 r. Nr 163, poz. 1012.

\section{Orzecznictwo}

Uchwała Sądu Najwyższego z dnia 26 września 1969 roku, III CZP 8/69, OSNC 1970/6/97.

Postanowienie Sądu Najwyższego z dnia 5 czerwca 2018 roku, IV CSK 27/18, LEX nr 2509658.

Studenckie Prace Prawnicze, Administratywistyczne i Ekonomiczne 37, 2021

(C) for this edition by CNS 